\title{
Indomethacin \& SARS-CoV-2: Prospects for clinical management of the inflammatory state
}

\author{
Satyanath R. Kodidala ${ }^{1}$, J. Sorout ${ }^{1}$, S. Jayachandra ${ }^{2}$, V. Narapogu ${ }^{3}$ \\ ${ }^{1}$ K.D. Medical College, Hospital and Research Centre, Mathura, India \\ ${ }^{2}$ Zydus Medical College, Dahod, Gujarat, India \\ ${ }^{3}$ Government Medical College, Budaun, Uttar Pradesh, India
}

\begin{abstract}
Severe acute respiratory syndrome - (SARS) is a pandemic (called as SARS-CoV-2 or COVID-19), severely affected by transmission and fatal disease caused by unknown coronavirus family of RNA virus (SARS-COV). Humans are under great threat among other species were non-identified. Phenotype can range from asymptomatic to fulminate cytokine storm which leads multiorgan failure resulting death. Still the world is eagerly waiting for antiviral drug to stop the corona virus infection. Previous studies found that indomethacin had ability to inhibit the RNA and DNA virus replication. Objectives. Interleukins (IL), Interferons (IFN) and metabolites like «cyclopentane cyclooxygenase» (COX 1/COX 2) are active against several RNA viruses. Experts have divided the SARS infection in three phases (Phase-1, 2, 3) based on severity of infection. In phase-3 there was «cytokine storm» due to exuberant inflammation observed which can damage organs and even fatal. We investigated that effect of indomethacin on COX inhibitor on coronavirus replication and cytokine storm in reducing the hyper inflammatory state. In this article we tried to assess the clinical management of inflammation due to SARS-COV-2 by Indomethacin. Results. Indomethacin can cause relief from the pain on taking deep breath in corona virus infected patients. Indomethacin can be considered safe and effective for prevention and treatment of coronavirus infection also antiviral activity. Conclusion: Indomethacin is a potent inhibitor of SARS CoV-2.
\end{abstract}

Key words: Indomethacin, COVID-19, SARS-COV2, inflammation

Author contributions. Dr. Satyanath R. Kodidala, Dr. Jitender Sorout and Dr. Srinivasa Jayachandra and V. Narapogu contributed the study concept, design and drafting of manuscript.

Conflict of interest statement. The authors declare no conflict of interest.

Received 11.08.2020. Accepted 11.11.2020

For citation: Satyanath R Kodidala, Sorout J, Jayachandra S, Narapogu V. Indomethacin \& SARS-CoV-2: Prospects for clinical management of the inflammatory state. RUDN Journal of Medicine. 2021;25(1):25—30. doi: 10.22363/2313-02452021-25-1-25-30

(C) Satyanath R. Kodidala., Sorout J., Jayachandra S., Narapogu V., 2021

This work is licensed under a Creative Commons Attribution 4.0 International License

https://creativecommons.org/licenses/by/4.0/ 


\title{
Индометацин и SARS-CoV-2: перспективы терапии воспаления в клинике
}

\author{
Сатьянатх Р. Кодидала' ${ }^{1}$, Дж. Сороут ${ }^{1}$, С. Джаячандра², В. Нарапогу ${ }^{3}$ \\ ${ }^{1}$ К.Д. Медицинский колледж, клиника и исследовательский центр, г. Матхура, Индия \\ ${ }^{2}$ Медицинский колледж Зидус, г. Даход, Гуджарат, Индия \\ ${ }^{3}$ Государственный медицинский колледж, г. Будаун, Уттар-Прадеш, Индия
}

\begin{abstract}
Аннотация. Тяжелый острый респираторный синдром (SARS) - это пандемия (называемая SARS-CoV-2 или COVID-19), вызванная неизвестным семейством коронавирусов PHK-вируса (SARS-COV). Фенотип может варьироваться от бессимптомного до молниеносного цитокинового шторма, который приводит к полиорганной недостаточности и смерти. Тем не менее мир с нетерпением ждет, когда противовирусный препарат остановит заражение вирусом короны. Предыдущие исследования показали, что индометацин обладает способностью подавлять репликацию РНК и ДНК-вирусов. Цель. Интерлейкины (IL), интерфероны (IFN) и метаболиты, такие как «циклопентанциклооксигеназа» (COX 1 / COX 2), активны против нескольких вирусов PHК. Эксперты разделили инфекцию SARS на три фазы (фазы $1,2,3)$ в зависимости от степени тяжести инфекции. В фазе 3 наблюдался «цитокиновый шторм» из-за сильного воспаления, которое могло повредить органы и даже привести к летальному исходу. Мы исследовали влияние индометацина на ингибитор ЦОГ на репликацию коронавируса и цитокиновый шторм в снижении гипервоспалительного состояния. В этой статье мы попытались оценить клиническое лечение воспаления, вызванного SARS-COV-2, с помощью индометацина. Полученные результаты. Индометацин может облегчить боль при глубоком вдохе у пациентов, инфицированных вирусом короны. Индометацин можно считать безопасным и эффективным для профилактики и лечения коронавирусной инфекции, а также противовирусной активностью. Выводы. Индометацин - мощный ингибитор SARS CoV-2.
\end{abstract}

Ключевые слова: индометацин, COVID-19, SARS-COV 2, воспаление

Вклад авторов. Доктор Сатьянатх Р. Кодидала, доктор Джитендер Сороут и доктор Шриниваса Джаячандра и Нарапогу В. внесли равный вклад в концепцию исследования, дизайн и составление рукописи.

Заявление о конфликте интересов. Авторы заявляют об отсутствии конфликта интересов.

Поступила 11.05.2020. Принята 06.06.2020.

Для цитирования: : Kodidala Satyanath R., Sorout J., Jayachandra S., Narapogu V. Indomethacin \& SARS-CoV-2: Prospects for clinical management of the inflammatory state // Вестник Российского университета дружбы народов. Серия: Медицина. 2021. Т. 25. №1.С. 25-30. doi: 10.22363/2313-0245-2021-25-1-25-30

\section{Introduction}

The global pandemic SARS-COV-2 started from Wuhan, CHINA which has shaken terribly the world. This virus pandemic challenged all healthcare professionals from treating infected people to prevention of infection. This corona virus rapidly infected people in china and spread all over the world. WHO declared this as pandemic disease. This coronavirus has been reported all the world and 1,14,19,529 cases with 5,33,780 deaths have confirmed with 4.674 death rate and continuing. Common symptoms of coronavirus infection were cough, fever, head ache and sputum production. While complicated symptoms are acute respiratory distress syndrome and cardiac injuries (1). Experts believed that SARS-COV-2 may be transmitted from bats to humans (2). The main host cell receptor for SARS-COV-2 
is ACE2 receptor (Angiotensin-converting enzyme 2 ), this is the main gate for entry of coronavirus and cause infection $(3,4)$ and pathogenesis reveals that all exposed people are infected and not all infected people develops serious problems, but completely depends on the immunity of specific person. The experts divided the infection into three phases, Phase- 1 asymptomatic incubation period may be or may not be with detectable virus, Phase-2 symptomatic with presence of virus and need of hospital, phase-3 severe respiratory symptomatic phase with viral load and inflammation due to cytokine burst, considered as dangerous phase.

\section{Phases of SARS-CoV-2 infection}

Experts described that infection can be divided into three phases depending on severity; each phase specific therapeutic treatment may be indicated or avoided. Again this specific treatment can be specific from person to person due to immune variation and also response of patients.

\section{Phase 1 (asymptomatic incubation)}

In this phase, person has contracted SARS-CoV-2, the infection starts and the immune system responds against the virus. Initial symptoms can be cough, fatigue, fever, nausea and diarrhea. Duration of this phase can be from 3-7 days. During this phase-1, a specific adaptive immune response will be required to break down the virus replication to avoid the progress of disease to severe. Immune responses and development could be certainly most important at this phase. When patient is at this stage antiviral can be helpful to inhibit the viral load and avoid further complications with the prevention of virus replication. Most probably only antiviral could be more effective to stimulate the immune system and avoiding the use of steroid or non-steroid anti-inflammatory drugs, and being able to take into consideration the administration of immune stimulants or plasma derived from cured patients by convalescent plasma could be beneficial.

Currently, there is evidence of antivirals drugs remdesivir, lopinavir/ritonavir, chloroquine and hydroxychloroquine for efficiency against SARS-CoV-2. If the progress of infection is limited in this phase and if virus is defeated, this will be a very good chance for the recovery without further complications.

\section{Phase 2 (symptomatic)}

The second phase of infection begins between the 10th and 14th day. A protective immune response of the body is impaired; the immune system was not able to protect body from the virus and deep respiratory tract infection, as the lungs.

The hypoxic phase starts; in this phase hospitalization and oxygen administration can be required. Cardiac involvement and clotting problems could take place in this phase and patients with underlying heart disease could have a greater risk of entering the serious clinical picture. Laboratory tests show a decrease in lymphocytes, an increase in transaminases and a moderate increase in pro-inflammatory markers.

The treatment that could be indicated is a continuous use of anti-viral drugs and, when the respiratory situation worsens, need to be started the support of oxygen and/ or use of anti-inflammatory drugs, antibiotics and the administration of LMWH-(Low-molecular-weightheparin) to prevent thromboembolic events.

\section{Phase 3 (severe)}

The third stage is the most serious, which can lead to the death of the patient. In this phase there is a hyperactive and systemic (not only lung) inflammatory state which is called Cytokine Storm (CS) and that can appear in the patient and, briefly, lead to respiratory distress syndrome (ARDS). In this phase inflammation marker values (IL-2, IL-6, GCSF, TNF-alpha, D-dimer, ferritin, etc.) are very high.The patient may have severe respiratory failure and cardiac shock.All the organs of different systems may see a worsened condition. Immunological therapies (corticosteroids, antiinterleukin 6, such as tocilizumab and sarilumab, IL-1 receptor antagonists such as anakinra or canakinumab, JAK-inhibitors, convalescent plasma transfusion) are necessaries at this severe stage to attempt the reduction of an aberrant storm cytokinic response. The prognosis for patients at this stage of disease is very severe [5-9].

\section{Indomethacin}

Indomethacin is an inexpensive drug, non-selective cyclooxygenase (COX) inhibitor that can inhibits COX-1 and COX-2 which catalyses the production of prostaglandins, and also used to treat a variety of 
inflammatory conditions. Indomethacin is a potent antiinflammatory agent, anti-viral and inhibits COX enzymes more potently than aspirin [10] with other mechanisms like inhibiting movement of PML(Polymorpho nuclear leucocytes), multidrug resistance protien. Amici et al. confirmed indomethacin possesses antiviral activity in vitro against SARS CoV (severe acute respiratory syndrome coronavirus) in monkey VERO cells as well as in vivo activity at relatively low doses (1 mg/ $\mathrm{kg}$ ) against canine coronavirus $(\mathrm{C} \mathrm{CoV})$ in dogs and also indomethacin possesses direct antiviral activity for SARS CoV and C CoV by blocking viral RNA synthesis many folds. Indomethacin is a NSAID which was introduced in the 1965 by FDA and has been used broadly for the treatment of pain and inflammatory conditions. There is a rational basis for the use of indomethacin in the treatment of Covid-19, in preference to other NSAIDs. [11].

Doctors in New York. US have been using indomethacin in the treating the COVID-19 symptoms for some time and now have experienced of using the indomethacin in more than 60 patients. Among Dr Jonathan Leibowitz, Dr Robert Rothstein and Dr Aline Benjamin, have shared their insights and experiences while treating the patients of COVID-19 [12].

Indomethacin, however, can also induce other side effects such as gastritis, renal dysfunction and platelet dysfunction,[13] which could be detrimental to COVID-19 patients with severe SARS-CoV-2 infection, especially if patients have multiorgan dysfunction/ failure resulting from cytokine storm (C.S). Furthermore, some authors have reported that NSAIDS such as ibuprofen may be detrimental in patients with SARS-CoV-2, causing more severe infection or leads to later complications such as emphysema, prolonged hospital stay, or lung cavitations, as has been reported in patients with bacterial pneumonia $[14,15]$. However, the WHO recently did not recommend against ibuprofen use for infection with SARS-CoV-2 [16]. Some studies have shown ibuprofen to cause decrease in sputum IL-6 in cystic fibrosis patients[17] and synovial fluid IL-6 in patients with knee osteoarthritis [17], which demonstrates that NSAIDS can lower IL-6 in human fluids. This lends biologic plausibility that COX inhibition with indomethacin could lower IL-6 levels in nasopharyngeal-respiratory tract secretions. Whether using lower doses of indomethacin (estarting with 25 mg 3 times daily) at first sign of infection (in outpatients after a positive nasopharynx swab confirmation) or for IPD with adequate organ function and no evidence of cytokine storm is conjectural, but use of this agent along with gastric protective agents (e.g., H2 blockers) may be prudent. Since cytokine storm is result of basically an inflammatory response, well-timed blunting of this cascade with indomethacin could conceivably lower inflammatory mediators such as TNF and IL-6 as well as superoxide free radicals, which invoke the cellular damage [13]. Perhaps a clinical strategy would be to monitor IL-6 levels (or C-reactive protein [CRP] as a surrogate marker), upon admission in noncritical patients and start indomethacin when IL-6 (or CRP) begins to rise, and subsequently monitor levels daily. Indeed, well-timed anti-inflammatory agents such as NSAIDS and corticosteroids have been suggested to reduce systemic inflammation prior to the development of overwhelming systemic inflammation/cytokine storm. [18] Indomethacin could be used alone or more likely, as an adjunct to antiviral therapy such as remdisivir, in noncritical patients. It would be interesting to monitor time to clearance of the antigen from upper respiratory secretion, antibody kinetics, and duration of symptomatic disease in patients treated with indomethacin. Given the cost and availability of this agent, indomethacin may warrant study in outpatients or admitted patients with documented infection with SARS-CoV-2 without evidence of cytokine storm.

\section{Mechanism of action of Indomethacin}

Indomethacin (INDO) is an NSAID and functions like most other NSAIDs. The effect of indomethacin is due to inhibition the synthesis of prostaglandins. Prostaglandins are produced primarily by the cyclooxygenase (COX) enzymes, and these prostaglandins are very critical mediators of inflammation, fever and pain, also involved in maintaining different system function (renal function, GI mucosa, and platelet activity-inhibition of this enzyme) by NSAIDs. COX-1 has involvement in the production of thromboxane A2 (a critical mediator of platelet aggregation) - thus, inhibition of this enzyme is likely responsible for the anti-platelet effects of NSAIDs. 
COX-1 appears for maintenance of GI mucosa, while COX-2 seems to be upregulated in inflamed tissues, and responsible for the production of prostaglandins which cause inflammation, fever and pain. Although COX-2 selective NSAIDs may have fewer GI associated side effects, indomethacin is a non-selective COX inhibitor. [19]

The NSAID Indomethacin has a potent antiviral activity against different coronaviruses, being effective against the canine (CCoV) and the human (SARS-CoV) coronaviruses. [20]. Moreover, INDO does not affect directly virus infectivity, binding to ACE-2 receptor or entry into target cells through respiratory system, but acts very early on the coronavirus replication cycle, selectively blocking viral RNA synthesis. INDO has been used for a long time as a potent antiinflammatory drug, acting by blocking COX-1 and COX-2 activity and inhibiting pro-inflammatory prostaglandin synthesis [21]. The antiviral effect, however, appears to be cyclooxygenase-independent, since it occurs at concentrations higher than those needed for COX inhibition (10-8,10-9M) [22]; in addition, the antiviral activity cannot be mimicked by the potent COX inhibitor Aspirin, which has no effect on either $\mathrm{CCoV}$ or SARS-CoV replication up to millimolar concentrations. Indomethacin has anti-viral activity; it down-regulates viral replication, and literature showed its anti-viral activity against rhabdovirus vesicular stomatitis virus, hepatitis B virus and coronavirus. [22][23]. Indomethacin (and most other NSAIDs) can impact most organ systems of the body (gastrointestinal, neurological, renal, hematologic and cardiopulmonary systems). As previously mentioned indomethacin is a non-selective COX inhibitor, and COX-1 is responsible for the production of prostaglandins involved in the maintenance of the gastric mucosa. Inhibition of this process can result in dyspepsia (indigestion), nausea, constipation, and diarrhea [24].

\section{Conclusions}

Although no randomized trial data was available for indomethacin for treatment or slowing progression of SARS-CoV-2 infection, these agents should be considered by the medical community as potentially worthy of further study as therapeutic adjuncts, given the relative safety, accessibility, and cost effective. As SARS-
CoV-2 infection can be divided into three phases: phase 1 , an asymptomatic or slightly symptomatic incubation period with or without detectable virus; phase 2, slightly symptomatic period with presence of virus; phase 3, severely symptomatic respiratory phase with high viral load and generalized hyperinflammatory state. The third is the most severe and dangerous described by a generalized hyperinflammatory state, a sudden release of cytokines into the circulation defined as «cytokine storm» (CS). Waiting to find antivirals directed against SARS$\mathrm{CoV}-2$, evidence has shown that reducing or stopping the hyperinflammatory state that occurs in some infected patients is effective in improving health. We believe that it is of utmost importance to properly manage the inflammatory/immune status of the infected patient. The use of indomethacin, as well as its proven efficacy in the prophylaxis and treatment of autoinflammatory diseases such as FMF or pericarditis, could be considered in all three stages of SARS-CoV-2 infection, especially in those patients at high risk of developing serious lung complications in a dramatically short time, in monotherapy or in combination, carefully monitoring possible drug interactions. Indomethacin, if used in the recommended doses, could be in monotherapy or in combination a safe and effective treatment for the prevention or reduction of cytokine strom in sars-CoV2. However, we believe that a combination of several drugs, each at a lower dosage than monotherapy, may be the most effective and tolerable solution to manage the patient's inflammatory state, particularly in phases two and three.

\section{References/ Библиографический список}

1. Huang C, Wang Y, Li X, et al. Clinical features of patients infected with 2019 novel coronavirus in Wuhan, China. Lancet. 2020;395(10223):497-506.

2. Zhou P, Yang X-L, Wang X-G, et al. A pneumonia outbreak associated with a new coronavirus of probable bat origin. Nature. 2020:10.1038/s41586-41020-42012-41587.

3. $\mathrm{Xu} \mathrm{H}$, Zhong $\mathrm{L}$, Deng $\mathrm{J}$, et al. High expression of ACE2 receptor of 2019-nCoV on the epithelial cells of oral mucosa. Int $J$ Oral Sci. 2020;12(1):8.

4. Cao Y, Li L, Feng Z, et al. Comparative genetic analysis of the novel coronavirus (2019-nCoV/SARS-CoV-2) receptor ACE2 in different populations. Cell Discovery. 2020;6(1). doi: 10.1038/s41421020-0147-1. 
5. Shi Y, Wang Y, Shao C, Huang J, Gan J, Huang X, Bucci E, Piacentini M, Ippolito G, Melino G. COVID-19 infection: the perspectives on immune responses. Cell Death Differ. 2020;27(5):1451-1454. doi: 10.1038/s41418-020-0530-3.

6. Arend W.P. Interleukin-1 receptor antagonist. Adv Immunol. 1993;54:167-227.

7. Burger D, Chicheportiche R, Giri JG, Dayer JM. The inhibitory activity of human interleukin-1 receptor antagonist is enhanced by type II interleukin-1 soluble receptor and hindered by type I interleukin-1 soluble receptor. J Clin Invest. 1995;96:38-41.

8. Conti P, Ronconi G, Caraffa A, Gallenga CE, Ross R, Frydas I, Kritas SK. Induction of pro- inflammatory cytokines (IL-1 and IL-6) and lung inflammation by Coronavirus-19 (COVI-19 or SARS-CoV-2): anti-inflammatory strategies. Masters P.S., Perlman, S. Coronaviridae. In: Knipe D.M., Howley P. (eds) Fields Virology. Lippincott Williams and Wilkins, Philadelphia, PA. 2013:825-858.

9. Brunton LL, Parker L, Blumenthal DK, Buxton ILO. Goodman and Gilman's Manual of Pharmacology and Therapeutics. New York: McGraw-Hill Medical, 2008:446-47.

10. Amici C, Di Caro A, Ciucci A, et al. Indomethacin has a potent antiviral activity against SARS coronavirus. Antivir Ther. 2006;11:1021-30. https://hospitalhealthcare.com/covid-19/indomethacin-has-a-positive-impact-on-covid-19-symptoms.

11. Brunton LL, Parker L, Blumenthal DK, Buxton ILO. Goodman and Gilman's Manual of Pharmacology and Therapeutics. New York, NY: McGraw. Hill Medical. 2008:446- 447.

12. Day M. Covid-19: ibuprofen should not be used for managing symptoms say doctors and scientists. BMJ. 2020;19:m1086.

13. Gupta R, Misra A. Contentious issues and evolving concepts in the clinical presentation and management of patients with COVID-19 infection with reference to use of therapeutic and other drugs used in co-morbid diseases (Hypertension, diabetes, etc.). Diabetes Metab Syndr. 2020;14:251-254.
14. Updated: WHO now doesn't recommend avoiding ibuprofen for COVID-19 symptoms. https://www.sciencealert.com/whorecommends-to-avoid-taking-ibuforfin-for-covid-19-symptoms.

15. Chmiel JF, Konstan MW, Accurso FJ, et al. Use of ibuprofen to assess inflammatory biomarkers in induced sputum: implications for clinical trials in cystic fibrosis. J Cyst Fibros. 2015;14:720-726.

16. Zhang W., Zhao Y., Zhang F., et al. The use of anti-inflammatory drugs in the treatment of people with severe coronavirus disease 2019 (COVID-19): the perspectives of clinical immunologists from China. Clin Immunol. 2020;214:108393.

17. Lucas S. The Pharmacology of Indomethacin. Headache. 2016 Feb;56(2):436-46.

18. Draper MP, Martell RL, Levy SB. Indomethacin-mediated reversal of multidrug resistance and drug efflux in human and murine cell lines overexpressing MRP, but not P-glycoprotein. $\mathrm{Br}$. J. Cancer. 1997;75(6):810-5.

19. Vane JR, Botting RM. Mechanism of action of antiinflammatory drugs. Adv Exp Med Biol. 1997;433:131-138.

20. Tegerder I, Pfeilschifter J, Geisslinger G. Cyclooxygenase- independent actions of cyclooxygenase inhibitors. FASEB J. 2001;15:2057-2072.

21. Amici C, La Frazia S, Brunelli C, Balsamo M, Angelini M, Santoro MG. Inhibition of viral protein translation by indomethacin in vesicular stomatitis virus infection: role of eIF2 $\alpha$ kinase PKR. Cell. Microbiol. 2015;17(9):1391-404.

22. Hoppmann RA, Peden JG, Ober SK. Central nervous system side effects of nonsteroidal anti-inflammatory drugs. Aseptic meningitis, psychosis, and cognitive dysfunction. Arch. Intern. Med. 1991;151(7):1309-13.

Corresponding author: Kodidala Satyanath R. - Assistant Professor, Department Of Physiology, K.D. Meical College, Hospital And Research Centre. Mathura, 281406, India. E-mail: ksatyanath1989@gmail.com

Satyanath R. Kodidala ORCID: 0000-0001-7830-7211

Sorout J. ORCID: 0000-0002-1510-0982

Jayachandra S. ORCID: 0000-0001-9473-8011

Ответственный за переписку: Кодидала Сатьянатх Р. - доцент кафедры физиологии, Медицинский колледж К.Д., Больница и исследовательский центр. Матхура, 281406, Индия. E-mail: ksatyanath1989@gmail.com

Сатьянатх P. Кодидала ORCID: /0000-0001-7830-7211

Сороут Дж. ORCID: 0000-0002-1510-0982

Джаячандра C. ORCID: 0000-0001-9473-8011 